\title{
Prevalence and risk factors associated with cutaneous warts in Fayoum primary school children
}

\section{Samar M.R. El-Tahlawy ${ }^{(1)}$, Naglaa A. El Sherbiny ${ }^{(2)}$, Marwa A. Nassar $^{(3)}$, Somaia H. Boureikaa $^{(4)}$, Talal A. Abdel-Raheem ${ }^{(5)}$}

(1) Dermatology Dept., Cairo University- Egypt

(2) Public Health \& Community Dept., Fayoum University, Egypt

(3) Dermatology \&STD and Andrology Dept., Fayoum University, Egypt

(4) Dermatology \&STD Dept., MOH- Egypt

(5) Dermatology \&STD and Andrology Dept., Fayoum University, Egypt

Corresponding author: prof .Talal A. Abd-ElRaheem

E-mail address: talasam@yahoo.com

Tel:01006600360

Fax: +2084636583

\section{ABSTRACT}

Cutaneous warts are benign papillomas of skin caused by human papilloma virus(HPV).HPV is transmitted by direct contact with contaminated skin or indirectly via objects carrying the virus. This cross sectional study included 2060 primary school students, who were selected from 2 rural (public) and 4 urban
(2 public and 2 private) primary schools in fayoum governorate. During the period from October 2017 to April 2018. The data were collected by questionnaire sheet.the prevalence of cutaneous warts was $4.7 \%$ among primary school children in Fayoum.

\section{KEY WORDS: Prevalence-Cutaneous warts-Primary school-Children.}

\section{INTRODUCTION}

Warts are common; benign skin infection throughout the world caused by the human papillomavirus (HPV). The common sites affected are the skin of the extremities, genital skin, and oral mucosa (Perveen et al., 2016). HPV is transmitted by direct contact with contaminated skin or indirectly via objects carrying the virus (kuwabara et al., 2015). There are many different clinical manifestations, such as verruca vulgaris, verruca plana, verruca plantaris, and genital warts (condyloma acuminata). Among them,

\section{SUBJECTS AND METHODS:}

This was a cross sectional descriptive study conducted in six primary schools in Fayoum district - Fayoum governorate. Fayoum Governorate is one of the governorates of Egypt in the middle of the country. verruca vulgaris and verruca plantaris are the most common (Sri et al., 2012). Sexual intercourse is the commonest cause of genital infection. Vertical transmission from infected mother to her infant occurs either through blood stream prior to birth, or during passing through the birth canal (Hacker et al., 2015). The most common treatment used are liquid nitrogen cryotherapy,electrotherapy and application of concentrated (30\%-50\%) salicylic acid (Bruggink et al., 2013).

The study population was primary school students, from both public and private schools. It consisted of children attending 2 private schools (600 children), children from 2 public schools in urban area (700 children) and 


\section{ETHICAL CONSIDERATION:}

This study was reviewed and approved by the Faculty of Medicine Research Ethical Committee. The official approval was obtained from: Directorate of Health Fayoum

Governorate; Directorate of Education Fayoum District; Director of the schools and students' parents.

\section{RESULTS}

The prevalence of wart lesions was $\mathbf{4 . 7 \%}$ of all examined students in the study as shown in Table (1).

Table (1): Prevalence of wart among study children

\begin{tabular}{|l|c|c|}
\hline & $\mathrm{N}$ & \% (95 \% CI) \\
\hline Having wart & 96 & $\mathbf{4 . 7}(\mathbf{3 . 8}-\mathbf{5 . 6})$ \\
\hline Not having wart & 1964 & 95.3 \\
\hline Total & $\mathbf{2 0 6 0}$ & $\mathbf{1 0 0 . 0}$ \\
\hline
\end{tabular}

There was highly statistical significant association between prevalence of warts and types of schools ( $p$-value $=0.001$ ), with higher prevalence of wart infection $(5.7 \%)$ in public schools than $(2.2 \%)$ in private schools as shown in Figure (1).

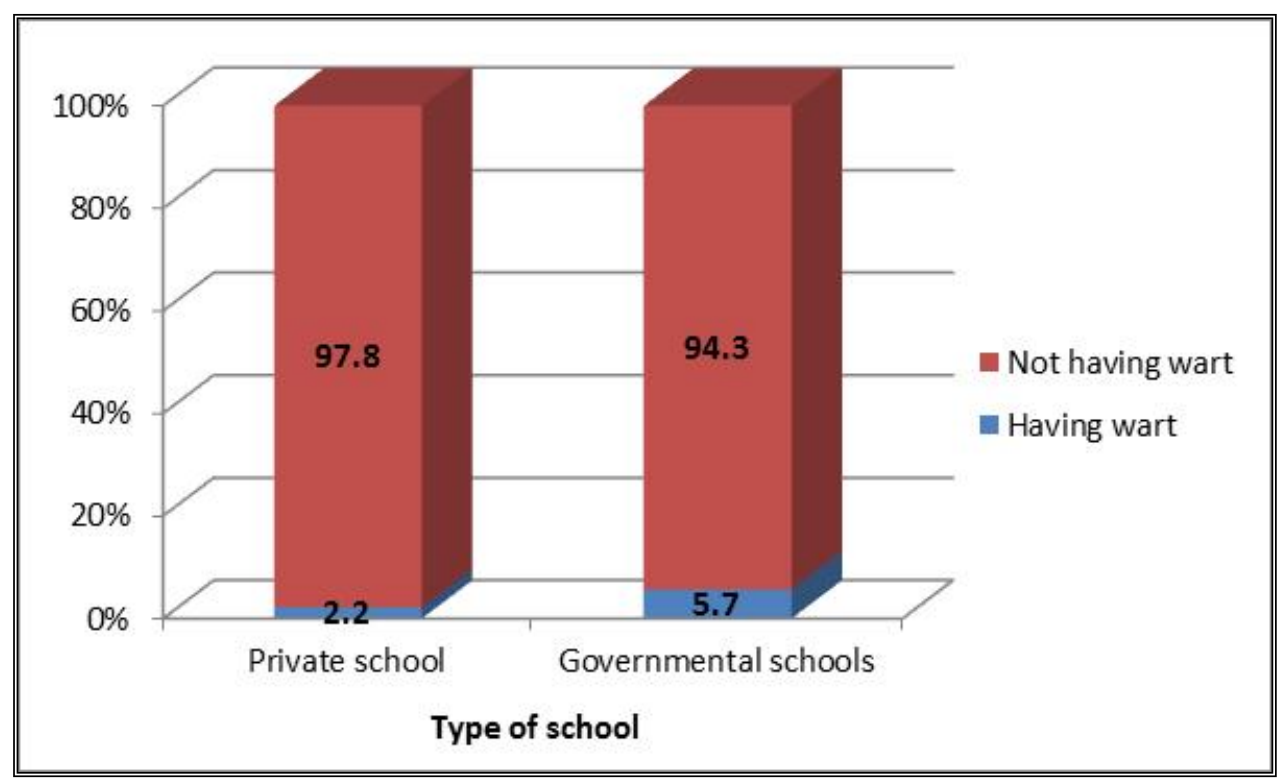

Fig (1): Prevalence of wart in studied schools 
As regards age of students, there was no statistically significant difference with ( $p$ value $=0.115$ ). Regarding sex, there was statistically significance difference with $(\mathrm{P}$ value $=0.047)$ with higher prevalence of wart infection $(5.7 \%)$ in males than in females
(3.9\%). According to residence there was statistically significance difference with ( $p$ value $=0.012$ ) with higher prevalence of wart infection $(6.2 \%)$ in rural areas than urban $(3.8 \%)$ as shown in Table (2).

Table (2): Relation of wart prevalence to demographic characteristics

\begin{tabular}{|c|c|c|c|c|c|}
\hline \multirow[t]{2}{*}{ Variable } & \multicolumn{2}{|c|}{$\begin{array}{l}\text { Having wart } \\
\quad(\mathrm{N}=96)\end{array}$} & \multicolumn{2}{|c|}{$\begin{array}{l}\text { Not having wart } \\
\qquad(\mathrm{N}=1964)\end{array}$} & \multirow[t]{2}{*}{ p-value } \\
\hline & \multicolumn{4}{|c|}{ Mean \pm SD } & \\
\hline Age (Years) & \multicolumn{2}{|c|}{$10.51 \pm 1.03$} & \multicolumn{2}{|c|}{$10.34 \pm 0.94$} & 0.115 (NS) \\
\hline Sex & $\mathbf{N}$ & $\%$ & $\mathbf{N}$ & $\%$ & p- value \\
\hline $\begin{array}{l}\text { Male } \\
\text { Female }\end{array}$ & $\begin{array}{l}51 \\
45\end{array}$ & $\begin{array}{l}5.7 \\
3.9\end{array}$ & $\begin{array}{l}841 \\
1123\end{array}$ & $\begin{array}{l}94.3 \\
96.1\end{array}$ & $0.047 *(\mathbf{S})$ \\
\hline Residence & $\mathbf{N}$ & $\%$ & $\mathbf{N}$ & $\%$ & p-value \\
\hline $\begin{array}{l}\text { Rural } \\
\text { Urban }\end{array}$ & $\begin{array}{l}47 \\
49\end{array}$ & $\begin{array}{l}6.2 \\
3.8\end{array}$ & $\begin{array}{l}713 \\
1251\end{array}$ & 93.896 .2 & $0.012 *(S)$ \\
\hline
\end{tabular}

$* \mathbf{p}<0.05$ is considered significant, $\mathbf{p}<0.001$ is considered highly significant.

Regarding parents' educational level, there was statistically significant difference between infected and healthy students with high percentage ohealthy students whose parents were highly educated to university level.

According to parents' occupation, there was statistically significant difference between infected and healthy students with high prevalence of infection was among students whose fathers were workers $(6.9 \%)$, and their mothers were housewives $(5.7 \%)$ as shown in Table (3).

Table (3): Relation of wart prevalence to economic characteristics

\begin{tabular}{|c|c|c|c|c|c|}
\hline \multirow{2}{*}{ Variable } & \multicolumn{2}{|c|}{ Having wart (96) } & \multicolumn{2}{|c|}{$\begin{array}{l}\text { Not having wart } \\
\text { (1964) }\end{array}$} & \multirow{2}{*}{ p-value } \\
\hline & $\mathrm{N}$ & $\%$ & $\mathrm{~N}$ & $\%$ & \\
\hline \multicolumn{6}{|c|}{ Father education } \\
\hline $\begin{array}{l}\text { Not educated } \\
\text { Primary } \\
\text { Secondary }\end{array}$ & $\begin{array}{l}22 \\
6 \\
46\end{array}$ & $\begin{array}{l}6.8 \\
8.1 \\
5.3\end{array}$ & $\begin{array}{l}301 \\
68 \\
822\end{array}$ & $\begin{array}{l}93.2 \\
91.9 \\
94.7\end{array}$ & $0.006 *(\mathrm{~S})$ \\
\hline
\end{tabular}




\begin{tabular}{|c|c|c|c|c|c|}
\hline University & 22 & 2.8 & 773 & 97.2 & \\
\hline \multicolumn{6}{|c|}{ Father occupation } \\
\hline Not working & 0 & 0.0 & 19 & 100.0 & \multirow{4}{*}{$<0.0001 * *(\mathrm{HS})$} \\
\hline Worker & 59 & 6.9 & 793 & 93.1 & \\
\hline Clerk & 16 & 4.3 & 360 & 95.7 & \\
\hline Others & 21 & 2.6 & 792 & 97.4 & \\
\hline \multicolumn{6}{|c|}{ Mother education } \\
\hline Not educated & 20 & 5.6 & 337 & 94.4 & \multirow{4}{*}{$0.020 *(S)$} \\
\hline Primary & 5 & 6.0 & 78 & 94.0 & \\
\hline Secondary & 51 & 5.8 & 831 & 94.2 & \\
\hline University & 20 & 2.7 & 718 & 97.3 & \\
\hline \multicolumn{6}{|c|}{ Mother occupation } \\
\hline Housewife & 68 & 5.7 & 1127 & 94.3 & \multirow{3}{*}{$0.005(\mathrm{~S})$} \\
\hline Working & 15 & 5.2 & 271 & 94.8 & \\
\hline Others & 13 & 2.2 & 566 & 97.8 & \\
\hline
\end{tabular}

$* p<0.05$ is considered significant, $p<0.001$ is considered highly significant.

\section{DISCUSSION}

The current study found that the prevalence of wart lesions was $4.7 \%$ of all examined students. This was nearly double the results reported by the study conducted in Honduras (Sierra et al., 2016) among children found that the prevalence of wart infection was $(2.3 \%)$ as well as study conducted in Taiwan the prevalence of warts was (2.4\%) (Yang et al., 2007) , and the prevalence of warts in primary school children reported in a study conducted in Dakahlia governorate, Delta region, Egypt was (2.3\%) (Kasim et al., 2013).

The current study found that residency had an obvious effect on infection with warts as the wart infection among children in rural locations was $(6.2 \%)$, while in urban locations was $(3.8 \%)$, that was in agreement with the study conducted in kingdom of Saudi Arabia as Amin et al. (2011) found that the prevalence of warts in rural areas was more than urban areas.

This study showed that there was statistically significant difference with higher prevalence of wart infection $(5.7 \%)$ in public schools than $(2.2 \%)$ in private schools, it indicated that the crowdness of the classes at public school had an impact on wart infection, that was in agreement with study conducted in Saudi Arabia recorded that wart infection was more in public schools $(9.8 \%)$ than in private schools (5.9\%) (Allayali et al., 2016).

\section{CONCLUSION AND RECOMMENDATION}

Warts remain a significant public health problem; common in childhood affects population from different countries with different social level and highly spread in schools.

According to the results of the current study, we concluded that we need more effort to eliminate this disease at different levels such as school, parents and students. All these levels play an important role in prevention of the disease.

A health behavior in school children is an important subject that must be instill in children as early as possible. It is a crucial point for prevention of different infectious diseases

School physicians and nurses should give their experience to the students and their 
families. This can prevent the transmission of several contagious skin diseases, including warts

\section{REFERENCES}

[1] Allayali A Z, Fallatah K, Alorfi S, and Mogharbe B (2016): Prevalence and Risk Factors of Verruca Vulgaris among Primary School Children in Madinah and Jeddah, Saudi Arabia J Clin Exp Dermatol Res ;8:1.

[2] Amin T T, Ali A and Kaliyadan F (2011): Skin disorders among male primary schoolchildren in Al Hassa, Saudi Arabia: prevalence and sociodemographic correlates - a comparison of urban and rural populations, Rural and Remote Health ;11: 1517.

[3] Bruggink S C, Eekhof J A, Egberts P F and Sophie C E (2013): Natural Course of Cutaneous Warts Among Primary School children:, Annals of Family Medicine; 11: 5.

[4] Hacker N F, Gambone J C, Hobel C J (2015): Hacker \& Moore's essentials of obstetrics and gynecology:276-285.

[5] Kasim K, Amer S, Mosaad M, Abdel-Wahed A and Allam $H$ (2013): Some Epidemiologic Aspects of Common Warts in Rural Primary School Children. ISRN Epidemiology: 6.

[6] Kuwabara A M, Rainer B M, Basdag H, Cohen B A (2015): Children with Warts: A Retrospective Study in an Outpatient Setting;32(5): 679-683.

[7] Perveen F, Baig $S$ and Alamgir $M$ (2016): Genotype Distribution of Human Papillomavirus in Warts. British Journal of Medicine and Medical Research 15(11): 1-10.

[8] Sierra M, Hernández K C, Delgado L Q and Martel B (2016): Prevalence of skin disorders in school children in Honduras;44(3).

[9] Sri J C, Dubina M I and Kao G F (2012): Generalized verrucosis, J. of the American Academy of Dermatol; 66, Issue (2): 292-311.

[10] Yang Y- C, Cheng Y-W, Lai C-S and Chen W (2007): Prevalence of childhood, warts in, Taiwan ;21(5): 643-649. 